\title{
Effect of Electrolysis Parameters on the Specific Surface Area of Nickel Powder: Optimization using Box-Behnken Design
}

\author{
Ali H. Abbar \\ Chemical Engineering Department, University of Al-Qadisiyah, Iraq \\ E-mail: ali.abbar@qu.edu.iq, aliabbar68@yahoo.com
}

doi: $10.20964 / 2019.01 .60$

Received: 3 September 2018 / Accepted: 4 November 2018 / Published: 30 November 2018

The effect of three electrolysis operating parameters on the specific surface area of electrolytic nickel powder was investigated by adopting response surface methodology approach. Box-Behnken design was selected to optimize the electrodeposition process and to estimate the effects and interactions of current density, nickel sulfate concentration, and temperature. BETS, XRD-diffraction, optical microscopy, and atomic force microscopy (AFM) were used to characterize the nickel powder. The results revealed that the current density has the major effect on the specific surface area of nickel powder followed by nickel sulfate concentration. No significant effect of temperature was observed. The optimum conditions for producing nickel powder at a maximum specific surface area of $1.05 \mathrm{~m}^{2} \mathrm{~g}^{-1}$ with an average particle size of $680.65 \mathrm{~nm}$ were a current density of $500 \mathrm{mAcm}^{-2}$, nickel sulfate concentration of $20 \mathrm{~g} \mathrm{~L}^{-1}$, and an operating temperature of $38{ }^{\circ} \mathrm{C}$. The corresponding current efficiency and energy consumption were $30 \%, 24.0 \mathrm{kWh} \mathrm{kg}^{-1}$ respectively. The prepared powder has better specifications than the industrial type (Type 255-carbonyl process). Analysis of variance (ANOVA) showed a high coefficient of determination $\left(\mathrm{R}^{2}\right)$ value of 0.978 , thus ensuring an adequately adjustment of the second-order regression model with the experimental data. The conformity results proved that the Box-Behnken design could be efficiently used to optimize the process parameters for the electrolytic preparation of metal powders.

Keywords: electrodeposition, nickel powder, surface area, Box-Behnken design, optimization

\section{FULL TEXT}

(C) 2019 The Authors. Published by ESG (www.electrochemsci.org). This article is an open access article distributed under the terms and conditions of the Creative Commons Attribution license (http://creativecommons.org/licenses/by/4.0/). 